\title{
Demonstration and Evaluation of an
} Advanced Oxidation Technology for Cooling Tower Water Treatment

Jesse Dean (NREL)

Dylan Cutler (NREL)

Gregg Tomberlin (NREL)

James Elsworth (NREL) 


\section{Disclaimer}

This document was prepared as an account of work sponsored by the United States Government. While this document is believed to contain correct information, neither the United States Government nor any agency thereof, nor the National Renewable Energy Laboratory, nor any of their employees, makes any warranty, express or implied, or assumes any legal responsibility for the accuracy, completeness, or usefulness of any information, apparatus, product, or process disclosed, or represents that its use would not infringe privately owned rights. Reference herein to any specific commercial product, process, or service by its trade name, trademark, manufacturer, or otherwise, does not constitute or imply its endorsement, recommendation, or favoring by the United States Government or any agency thereof, or the National Renewable Energy Laboratory. The views and opinions of authors expressed herein do not necessarily state or reflect those of the United States Government or any agency thereof or the National Renewable Energy Laboratory. Funding provided by the U.S. General Services Administration.

The work described in this report was funded by the U.S. General Services Administration and the U.S. Department of Energy] under Contract No. 47PA0117C0009.

\section{Acknowledgements}

GSA's Proving Ground: Kevin Powell - Director

GSA Region \#8 - Doug Baughman - Energy Management Specialists / OFM, Tyler Cooper - Mechanical Engineer

Tenfold Information Design Services: Andrea Silvestri

National Renewable Energy Laboratory: Michael Deru, Kosol Kiatreungwattana

\section{For more information contact:}

Jesse Dean

Senior Engineer

National Renewable Energy Laboratory

Email: jesse.dean@nrel.gov

GSA's GPG program and DOE's High Impact Technology (HIT) Catalyst program enable federal and commercial building owners and operators to make sound investment decisions in next generation building technologies based on their real-world performance. 


\section{Executive Summary}

This GSA Proving Ground project assessed the performance of an alternative water treatment (AWT) system manufactured by Silver Bullet for a 500-ton cooling tower at Building 95, at the Denver Federal Center in Denver, Colorado. Cooling tower water consumption is one of the largest potable water loads in commercial buildings in the United States, as more than $28 \%$ of water use is from heating and cooling systems (EPA n.d.). A cooling tower uses an evaporative cooling process to reject heat to the atmosphere from a water-cooled chilled water plant. The continuous evaporation of water from the condenser leaves behind the natural mineral content it carried (silica, calcium, magnesium, chloride). Thus, the remaining condenser water will have an ever-increasing concentration of impurities as more water evaporates. These impurities will eventually precipitate out (because water can hold only so much), resulting in solid precipitate. This solid precipitate is commonly called scale and collects on surfaces, inhibiting performance. Typically, cooling tower water is treated using three methods: adding scale inhibitors that allow water to hold a higher concentration of minerals, using corrosion inhibitors that decrease corrosion in piping systems, and introducing biocides and algicides that mitigate biological growth in an open-air cooling tower.

In addition to chemical treatments, a portion of the cooling tower water is typically drained as tower blowdown, and the tower is refilled with fresh makeup water. This reduces the chemical and mineral concentration of the remaining condenser water. It also reduces the cycles of concentration of the cooling tower and increases annual cooling tower water usage. GSA operation and maintenance procedures require that cooling towers have a cycle of concentration of 2 or greater. A higher cycle of concentration correlates with less blowdown and reduced makeup water consumption for the cooling tower.

The AWT technology evaluated at Building 95 at the Denver Federal Center is a nontoxic photochemicalbased cooling tower water treatment technology promoted as a simpler water treatment technology that uses an advanced oxidation process to treat cooling tower makeup water. It pulls air from the surrounding environment, which then passes through patented sleeves that contain ultraviolet lamps and other proprietary components that modify the ambient air, creating negatively charged oxygen atoms. These atoms diffuse into the water, forming highly reactive hydroxyl and other radicals. The hydroxyl radicals and other oxidants help to oxidize minerals and contaminants in the water, kill bacteria, reduce biofilm, and break down calcium buildup (inhibiting scaling). The dissolved oxidants combine with water molecules to create hydrogen peroxide, a lasting biocide, though a small amount of biocide was still added to the system that was demonstrated. With this system, no additional standard cooling tower water treatment chemicals are typically needed, except that biocides such as bromide or other algicides may be used to control algae growth in the summer.

The installation of the product is simple. The unit is mounted on the wall, a pipe with an air diffuser to treat the cooling tower water is routed from the device to the cooling tower basin, and no significant modification of the current cooling tower water treatment system is required.

Building 95 at the Denver Federal Center is a $163,206 \mathrm{ft}^{2}$, two-story office/laboratory building that was constructed in 1999. The major tenant is the U.S. Department of Interior. Building 95 has two 250 -ton 
water-cooled centrifugal chillers that supply chilled water to the facility. The cooling tower is a 500-ton induced draft cooling tower, with two cooling tower cells and two-speed fan motors.

The AWT technology was evaluated with a combination of on-site chiller plant energy measurements, cooling tower makeup water measurements, and outputs from the building automation system. Electrical energy for the chilled water plant and cooling tower makeup water was metered directly through GSA's automated metering program, and 15-minute interval data were available from 2014 to 2017. Outside air conditions, including dry bulb temperature, dew point temperature, wind speed, and precipitation, were recorded on an hourly basis from the National Renewable Energy Laboratory's Solar Radiation Research Laboratory and daily average values of average dry bulb temperature, minimum dry bulb temperature, maximum dry bulb temperature, average dew point, average wind speed, and total daily precipitation were taken from Weather Underground for Denver, Colorado. The condenser water supply and return temperatures for the main condenser loop were trended via the building automation system at a recording interval of 15 minutes for 2016-2017. Condenser pump \#1 and \#2 speeds were trended via the building automation system at a recording interval of 15 minutes for 2016-2017.

The AWT technology was installed in December 2014, and calendar year 2014 was used as the baseline year for the study. The AWT contractor analyzed the condition of the condenser tubes in early 2015 and noted that the condenser tubes were partially fouled with scale buildup. In addition, the 2017 electrical meter data and condenser water meter data had the fewest data drop outs, so 2017 was used as the post retrofit savings case. The National Renewable Energy Laboratory did not install any secondary data acquisition systems and did not perform the same level of measurement and verification as other GSA Proving Ground projects because this project was financed by GSA Region 8 and not the national GSA Proving Ground. In addition, the existing metering system data and building automation system data were used to characterize the cooling tower makeup water savings for both the baseline period and post-retrofit period. A listing of quantitative and qualitative performance objectives and measurement and verification results are provided in Table 1.

\section{Table 1: Performance Objectives}

\begin{tabular}{|c|c|c|c|}
\hline $\begin{array}{l}\text { Quantitative } \\
\text { Objectives }\end{array}$ & Success Criteria & Metrics \& Data & $\begin{array}{l}\text { Measurement and } \\
\text { Verification Results }\end{array}$ \\
\hline Water Savings & $\begin{array}{l}>10 \% \text { reduction in cooling } \\
\text { tower water makeup } \\
\text { (gal/kWh) }\end{array}$ & $\begin{array}{l}\text { - Cooling tower makeup water } \\
\text { - Chiller plant energy usage } \\
\text { - Outside air temperature, dew } \\
\text { point, wind speed, and } \\
\text { precipitation }\end{array}$ & $\begin{array}{l}\text { Met: Annual water } \\
\text { reduction } 22.7 \% \text { to } 29.7 \%\end{array}$ \\
\hline $\begin{array}{l}\text { Reduction in } \\
\text { Chemical Costs }\end{array}$ & $\begin{array}{l}>90 \% \text { reduction in annual } \\
\text { chemical costs }\end{array}$ & $\begin{array}{l}\text { - Pre and post installation } \\
\text { annual chemical costs }\end{array}$ & $\begin{array}{l}\text { Met: Elimination of all } \\
\text { chemicals other than } \\
\text { biocides }\end{array}$ \\
\hline Water Chemistry & $\begin{array}{l}\text { Meets or exceeds GSA cooling } \\
\text { tower water chemistry } \\
\text { requirements }\end{array}$ & $\begin{array}{l}\text { - Pre and post installation water } \\
\text { chemistry reports }\end{array}$ & $\begin{array}{l}\text { Met: Passed GSA water } \\
\text { chemistry requirements } \\
\text { for all metrics other than } \\
\text { oxidation reduction } \\
\text { potential }\end{array}$ \\
\hline Cost-Effectiveness & $\begin{array}{l}\text { Simple payback (SPP); Savings } \\
\text { to Investment ratio (SIR) }\end{array}$ & - Payback <10 years; SIR >1. & $\begin{array}{l}\text { Met: SPP of } 6.2 \text { yrs.; SIR of } \\
2.4\end{array}$ \\
\hline Ease of Installation & $\begin{array}{l}\text { Less than 2-day installation } \\
\text { time }\end{array}$ & Labor hours to install technology & $\begin{array}{l}\text { Met: Less than } 1 \text { day to } \\
\text { install }\end{array}$ \\
\hline
\end{tabular}


The estimated annual cooling tower makeup water savings is 527,791 gallons/year, with a range of estimated savings from 433,288 gallons/year to 622,307 gallons/year. The estimated total annual cooling tower makeup water savings is $26.3 \%$, with a lower bound estimate of $22.7 \%$ and a higher bound estimate of $29.7 \%$. The equipment costs for the two AWT processing units was $\$ 29,780$, the installation cost was $\$ 2,970$, for a total cost of $\$ 32,750$ (\$65.5/ton). The 12-month service agreement was $\$ 3,300$ (\$275 per month). The annual water savings, cost savings, and economics for the system are provided in Table 2.

Table 2: Annual Cost Savings and Economics

\begin{tabular}{|c|c|c|c|c|}
\hline & $\begin{array}{l}\text { Baseline } \\
\text { (Before) }\end{array}$ & $\begin{array}{r}\text { Tested } \\
\text { Technology } \\
(\text { After) })^{1}\end{array}$ & $\begin{array}{r}\text { Difference w/ } \\
\text { Local Sewer + } \\
\text { Water Rate } \\
\text { (\$7.14/kGal.) }\end{array}$ & $\begin{array}{r}\text { Difference } \\
\text { w/ GSA Avg. } \\
\text { Water Rate } \\
\text { \$16.76/kGal. }\end{array}$ \\
\hline Installation (\$) & $\mathrm{N} / \mathrm{A}$ & $\$ 32,750$ & $\$ 32,750$ & $\$ 22,487$ \\
\hline Installation Cost (\$/ton) & & $\$ 65.50$ & $\$ 65.50$ & $\$ 44.97$ \\
\hline Annual Maintenance & $\$ 5,855 / \mathrm{yr}$ & $\$ 3,333 / \mathrm{yr}$. & $\$ 2,522 / y r$ & $\$ 2,522 / y r$. \\
\hline $\begin{array}{r}\text { Annual Water Consumption } \\
\text { (Gallons/yr.) }\end{array}$ & $2,003,273$ & $1,475,482$ & 527,791 & 527,791 \\
\hline Annual Water Costs(\$/yr.) & $\$ 14,303$ & $\$ 10,535$ & $\$ 3,768$ & $\$ 8,846$ \\
\hline Annual Energy Costs (\$/yr.) & $\$ 0$ & $\$ 1,041$ & $\$ 1,041$ & $\$ 578$ \\
\hline Simple Payback & & Yrs. & 6.2 & 2.1 \\
\hline Savings-to-Investment Ratio & \multicolumn{2}{|c|}{ Integer value between 0 and 100} & 2.4 & 7.2 \\
\hline
\end{tabular}

The new cooling tower operations and maintenance contract for the AWT saved the site $\$ 2,522$ per year, with a $50 \%$ reduction in man hours. The two AWT units had a combined power draw of $1.2 \mathrm{~kW}$ and operated for 8,760 hrs./yr., for a total power consumption of 10,512 kWh/yr. and an estimated energy cost of $\$ 1,137 / \mathrm{yr}$. The annual water cost savings was $\$ 3,768$ per year (using a combined water sewer rate of $\$ 7.14 / \mathrm{kgal}$.) and the simple payback period is 6.2 years, with a savings-to-investment ratio of 2.4 , using a 15 year project lifetime. Given that for future installations of this size, both GSA and the vendor have confirmed that just one AWT processing unit would be needed, the installed cost for that case was estimated to be $\$ 22,487$, with an energy usage of $5,250 \mathrm{kWh} / \mathrm{yr}$., at a cost of $\$ 578 / \mathrm{yr}$. Using GSA's national average combined water and sewer rate of $\$ 16.76 / \mathrm{kgal}$., the annual water savings would have been $\$ 8,846 / y r$, with a simple payback of 2.1 years and a savings-to-investment ratio of 7.2.

The installation requires only simple wall mounting and the injector hose is connected to the cooling tower basin. Thus, the total installation time of only a few hours was much less than the performance metric requirement of less than 2 days.

For 2017, the annual average cycle of concentration was 9.54 and all of the tower water chemistry values were within the GSA designated ranges. The operations and maintenance contractor servicing the facility continued its service contract and, after an initial descaling period, no additional water treatment chemicals were added to the system other than the bromine/chlorine biocides to prevent biological 
growth, significantly reducing the chemical usage of the tower and lowering the environmental impact of the chemicals being drained via the blow down cycle. As noted above, this also resulted in a $50 \%$ reduction in labor hours to service the cooling towers and a \$2,522 operations and maintenance savings per year.

This AWT product was analyzed as a potential retrofit option for smaller building applications that may not have full-time or on-site cooling tower operations and maintenance contractors. This product is unique in that it can be used without additional monitoring aside from a low-cost service agreement.

For future installations, Denver Federal Center staff have indicated that they would suggest leasing the technology as part of the service contract with the vendor instead of purchasing it, given that the installation is very quick and potential removal of the technology is not disruptive to the balance of system. 


\section{Table of Contents}

EXECUTIVE SUMMARY III

I. INTRODUCTION 1

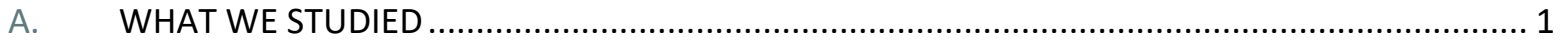

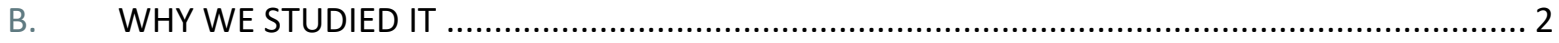

II. $\quad$ EVALUATION PLAN

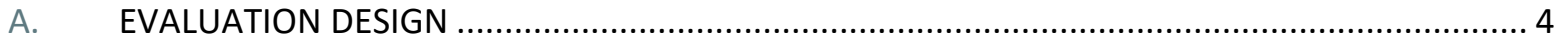

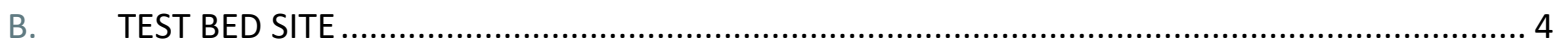

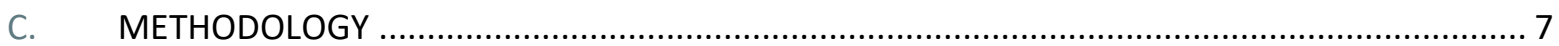

III. DEMONSTRATION RESULTS 11

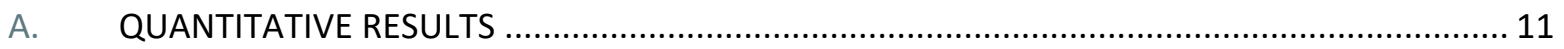

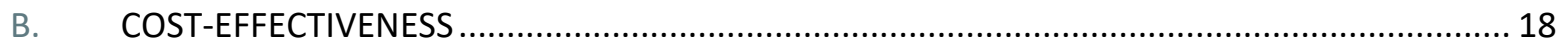

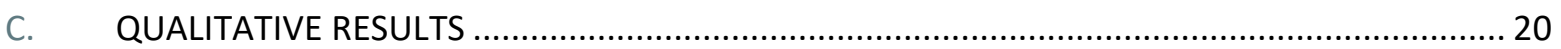

IV. SUMMARY FINDINGS AND CONCLUSIONS 21

A. OVERALL TECHNOLOGY ASSESSMENT AT DEMONSTRATION FACILITY ............................... 21

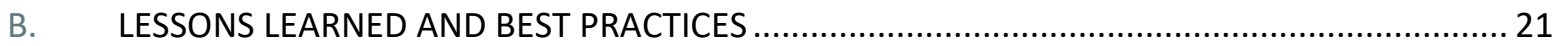

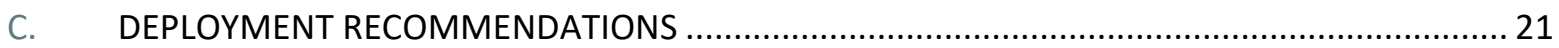

$\begin{array}{ll}\text { V. DEPLOYMENT GUIDANCE (GSA ONLY) } & 27\end{array}$

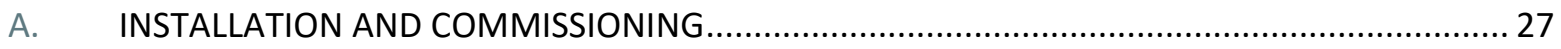

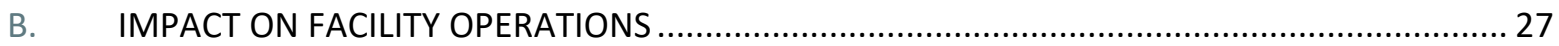

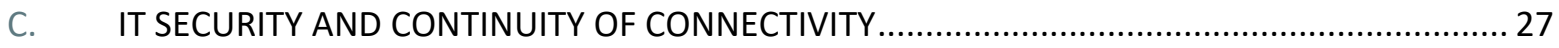

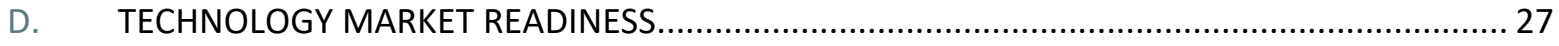

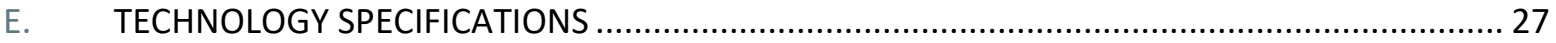

\begin{tabular}{ll} 
VI. & APPENDICES \\
\hline
\end{tabular}

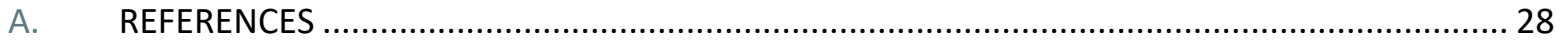

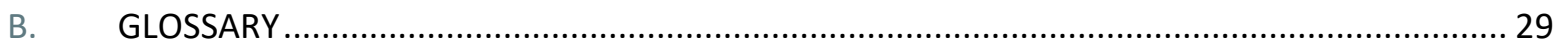

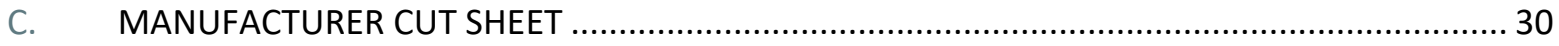




\section{Introduction}

\section{A. WHAT WE STUDIED}

A cooling tower uses the evaporative cooling process to reject heat to the atmosphere from a watercooled chilled water plant. Cooling towers are commonly applied to water-cooled chilled water plants in large commercial buildings. The continuous evaporation of pure water from the condenser leaves behind any natural mineral content the water carried (silica, calcium, magnesium, chloride). Thus, the remaining condenser water will have an ever-increasing concentration of impurities as more water evaporates. These impurities eventually will precipitate out (because water can hold only so much), resulting in solid precipitate. This solid precipitate is commonly called scale and will collect on various surfaces it touches. Scale has a substantial detrimental effect on heat transfer surfaces; it lowers the efficiency of the heat transfer process, causing the chiller to use increasingly more energy over time to achieve the same level of cooling. In addition to scale, biofilms also have a significant impact on heat transfer efficiency. The high-water content of biofilms creates an insulating layer that inhibits energy transfer to a much greater degree than mineral scale alone (because of the high specific heat of water). Typical water treatment consists of injecting chemicals into the condenser water for the following three purposes:

- Chemicals called "scale inhibitors" alter the natural ability of water so that it can hold a higher concentration of minerals.

- Chemicals called "corrosion inhibitors" decrease corrosion in piping systems.

- Chemicals called "biocides" and "algicides" mitigate biological growth in the cooling tower, where warm water is exposed to air.

In addition to the chemical treatments, a portion of the cooling tower water is typically drained off as tower "blowdown" or "bleed-off." This water volume is then replaced by fresh "makeup" water. This process lowers the chemical and mineral concentration of the remaining condenser water. It also lowers the cycle of concentration $(\mathrm{COC})$ of the cooling tower and increases annual cooling tower water usage. GSA requires that cooling towers have a $\mathrm{CoC}$ of 2 or greater. A higher $\mathrm{CoC}$ will lower both blowdown and total water consumption.

The Silver Bullet alternative water treatment (AWT) technology is a non-chemical-based cooling tower water treatment technology. It is promoted as a simpler water treatment technology that can reduce cooling tower blowdown by increasing the CoCs, which reduces monthly chemical costs, monthly operation and maintenance costs, and the amount of scale that collects on condenser water tubes and cooling towers.

The product uses an advanced oxidation process. It pulls air from the surrounding environment, which then passes through patented sleeves that contain ultraviolet lamps and other proprietary components that modify the air, creating negatively charged oxygen atoms. These diffuse into the water, forming highly reactive hydroxyl and other radicals. The hydroxyl radicals and other oxidants help to oxidize

minerals and contaminants in the water, kill bacteria, reduce biofilm, and break down calcium buildup 
(inhibiting scaling). The dissolved oxidants combine with water molecules to create hydrogen peroxide, which acts as a lasting biocide, though a small amount of additional biocide is typically still added with this system. With this system, no additional standard cooling tower water treatment chemicals need be used, except that biocides such as bromide or other algicides can be used to control algae growth in the summer.

The product is the size of a large electrical panel and can be retrofitted in less than a day. It is typically rented on a monthly basis at a cost that is comparable to traditional chemical treatments. A picture of the product is provided in Figure 1 (Silver Bullet n.d.-a).

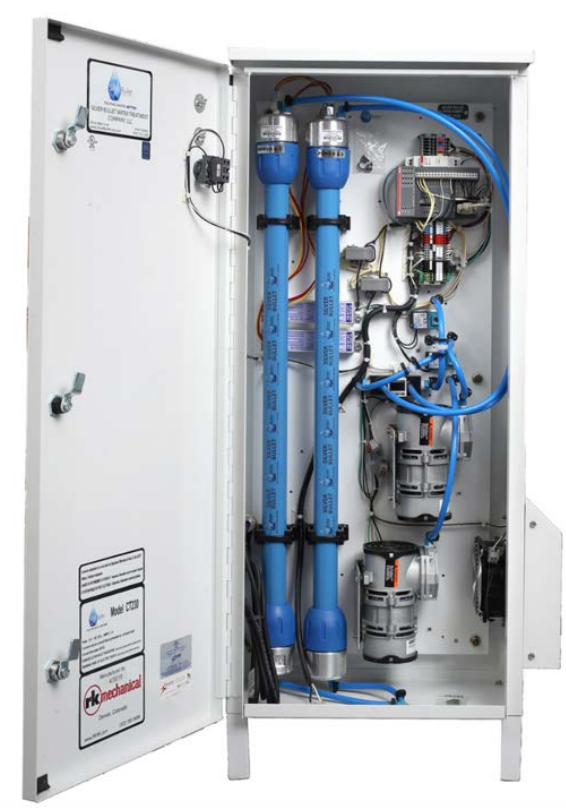

\section{Figure 1: Non-Chemical-Based Cooling Tower Water Treatment Technology}

The process uses an EPA recognized effective biocide via the advanced oxidation process and is easily automated and controlled. The vendor offers a smaller unit for cooling towers up to 400 tons or 1,200 gallons per minute (gpm) and a larger unit for systems up to 2,000 tons or $6,000 \mathrm{gpm}$. The smaller units draw 396 watts of power and the larger unit draws 720 watts of power while operating.

\section{B. WHY WE STUDIED IT}

Cooling tower-related water consumption is one of the largest potable water loads within buildings in the United States. Figure 2, a breakdown of water consumption in office buildings, shows that more than $28 \%$ of building water use is associated with heating and cooling. This is by far the dominant water use case, owing largely to the evaporative cooling demands from either water-cooled cooling towers or evaporation-based air-conditioning systems. 


\section{End Uses of Water in Office Buildings}

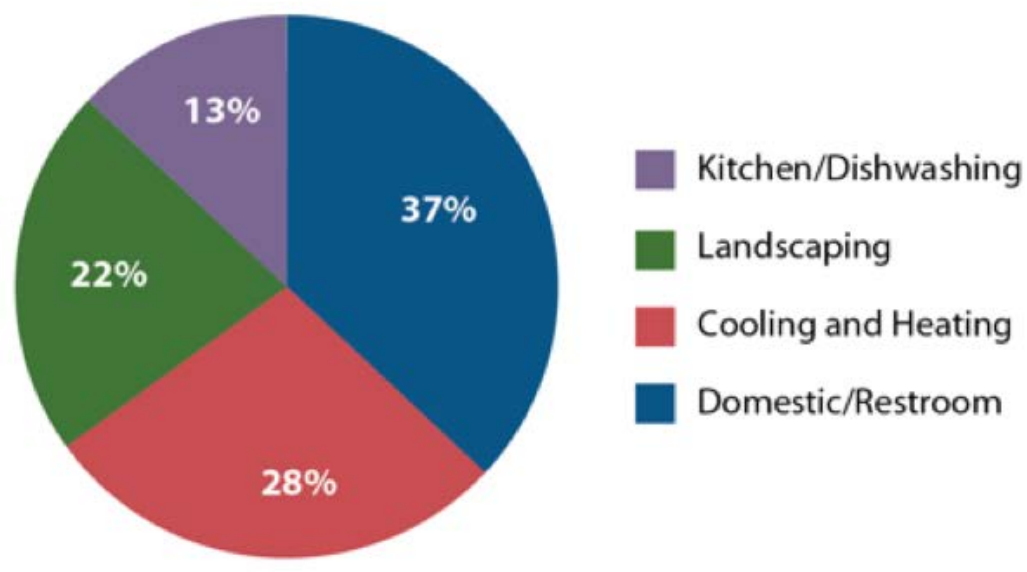

Figure 2: Office Building Water End Uses (EPA n.d.)

Cooling towers can be found in all states throughout the country, and this technology can save water in every climate zone. Facilities located in hotter climates with a cooling season that lasts for more than 56 months per year, though, will use their cooling towers more and have greater cooling tower water savings as a result.

The Denver Federal Center is located in Colorado and GSA Region 8. In GSA Region 8, cooling towers are installed at thirty of the larger buildings in the region. Although the number of cooling towers in each GSA region is unknown, it is expected that each region has numerous cooling towers that could benefit from reducing water consumption. 


\section{Evaluation Plan}

\section{A. EVALUATION DESIGN}

The primary focus of this evaluation was measuring cooling tower makeup water usage pre- and postinstallation of the AWT. In addition, annual reductions in cooling tower chemical costs, monthly water chemistry reports, ease of installation, and overall cost effectiveness were evaluated.

Table 3 lists the performance objectives, success criteria, and metrics used to evaluate each of the objectives.

Table 3: Performance Objectives

\begin{tabular}{|l|l|l|}
\hline Quantitative Objectives & Success Criteria & Metrics \& Data \\
\hline Water Savings & $\begin{array}{l}>10 \% \text { reduction in cooling tower } \\
\text { water makeup }\end{array}$ & $\begin{array}{l}\text { - Cooling tower makeup water } \\
\text { - Chiller plant energy usage } \\
\text { - Outside air temperature, dew point, } \\
\text { wind speed, and precipitation }\end{array}$ \\
\hline $\begin{array}{l}\text { Reduction in Chemical } \\
\text { Costs }\end{array}$ & $\begin{array}{l}>90 \% \text { reduction in annual chemical } \\
\text { costs }\end{array}$ & $\begin{array}{l}\text { - Pre and post installation annual } \\
\text { chemical costs }\end{array}$ \\
\hline Water Chemistry & $\begin{array}{l}\text { Meets or exceeds GSA cooling tower } \\
\text { water chemistry requirements }\end{array}$ & $\begin{array}{l}\text { - Pre and post installation water } \\
\text { chemistry reports }\end{array}$ \\
\hline Cost-Effectiveness & $\begin{array}{l}\text { Simple payback; Savings to } \\
\text { investment ratio (SIR) }\end{array}$ & - Payback <10 years; SIR $>1$ \\
\hline Qualitative Objectives & Success Criteria & Metrics \& Data \\
\hline Ease of Installation & Less than 2-day installation time & Labor hours to install technology \\
\hline
\end{tabular}

\section{B. TEST BED SITE}

Building 95 at the Denver Federal Center is a 163,206 $\mathrm{ft}^{2}$, two-story office/laboratory building that was constructed in 1999. The major tenant is the U.S. Department of Interior. Building 95 currently houses the National Water Quality Laboratory - the flagship analytical facility for the U.S. Geological Survey of the U.S. Department of the Interior (Figure 3). 


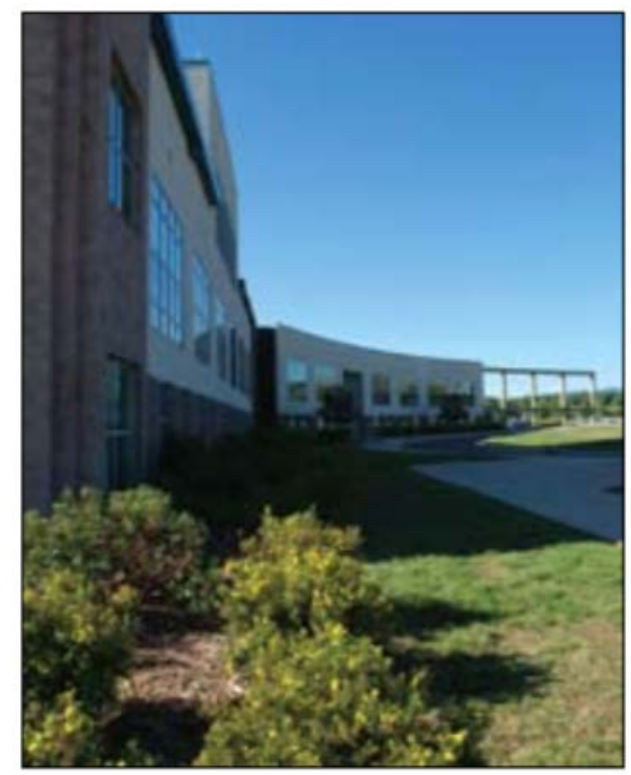

Figure 3: Building 95 at the Denver Federal Center

Building 95 has two 250 -ton water-cooled centrifugal chillers that supply chilled water to the facility. The chiller is rated at $0.5 \mathrm{~kW} /$ ton and has a rated evaporator flow rate of $350 \mathrm{gpm}$ and a rated condenser flow rate of $750 \mathrm{gpm}$. There are two $20 \mathrm{hp}$ centrifugal condenser water pumps, rated at 750 gpm at $75 \mathrm{ft}$ of head, serving the two chillers. The cooling tower is an induced draft cooling tower, with two cooling tower cells and two-speed fan motors (Figure 4). 


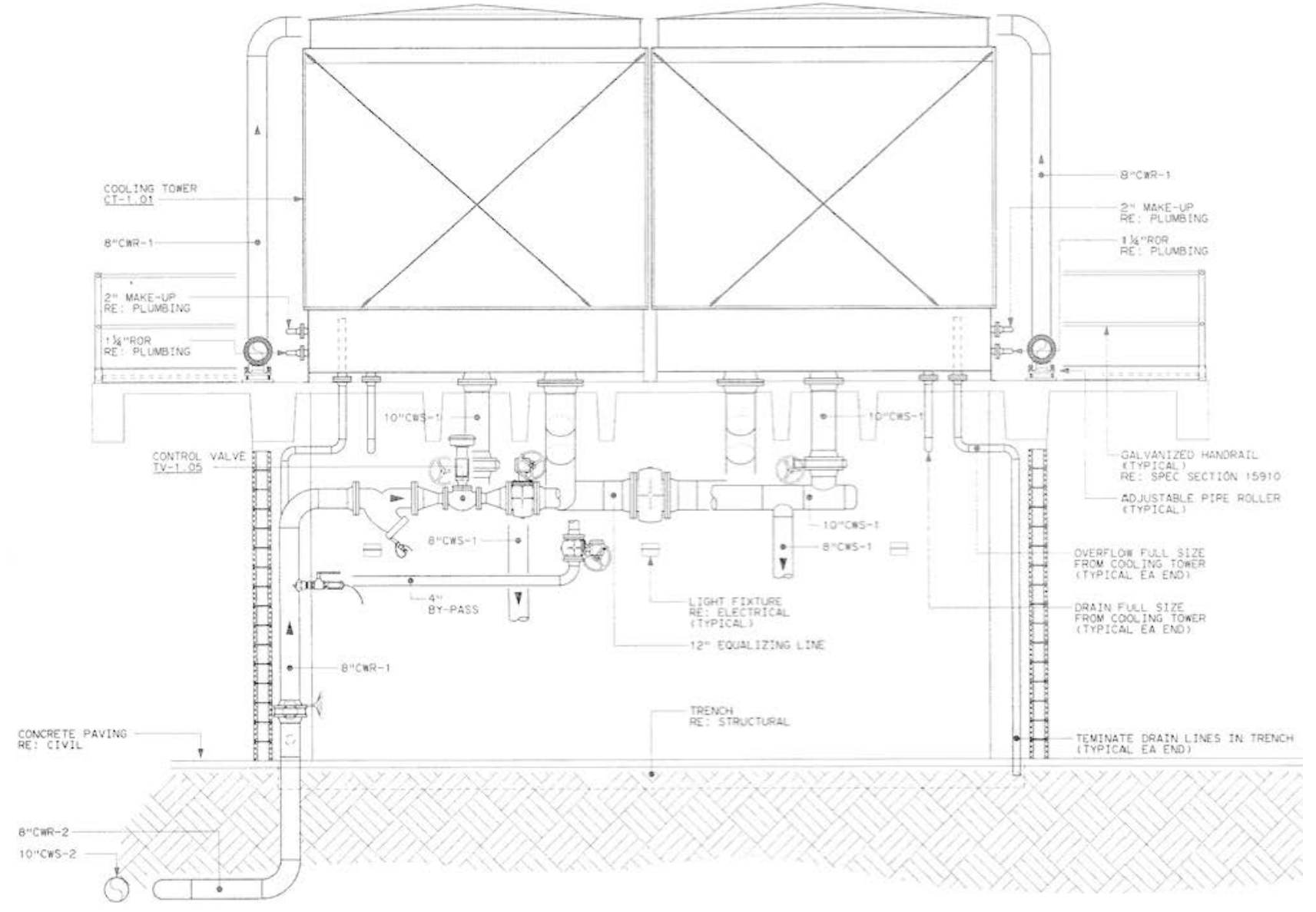

Figure 4: Building 95 Induced Draft Cooling Tower

Figure 5 provides a picture of the AWT treatment system installed in building 95 .

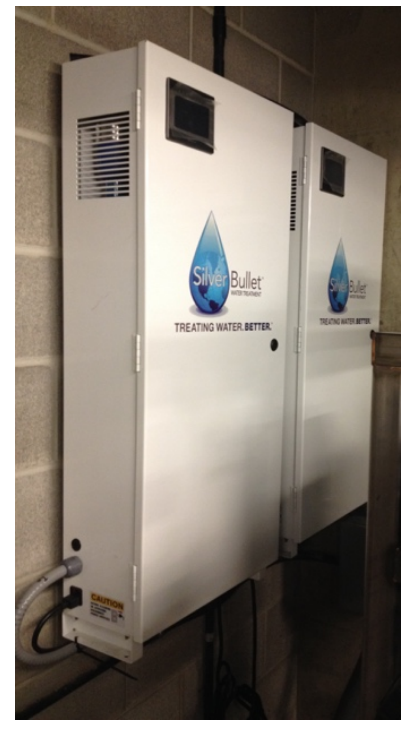

Figure 5: Building 95 Alternative Water Treatment System 


\section{METHODOLOGY}

\section{Quantitative Study Design}

The AWT technology was evaluated through a combination of on-site chiller plant energy measurements, cooling tower makeup water measurements, and measurements taken from the Building Automation System (BAS). A high-level description of the monitoring points is provided below:

\section{On-Site Submetering}

- Electrical Energy - Building 95 has an automated submeter for the chilled water plant that records 15-minute electricity usage for the entire chilled water plant, including chillers, cooling tower fans, condenser water pumps, and chiller primary and secondary pumps.

- Cooling Tower Water - The cooling tower makeup water is metered directly by an on-site water meter and provides 15-minute interval cooling tower water usage data dating back to 2013.

\section{Outside Air Data}

- Outside Air Conditions - Outside air conditions, including dry bulb temperature, dew point temperature, wind speed, and precipitation, were analyzed on an hourly basis by the National Renewable Energy Laboratory's (NREL's) Solar Radiation Research Laboratory and daily average values of average dry bulb temperature, minimum dry bulb temperature, maximum dry bulb temperature, average dew point, average wind speed, and total daily precipitation were recorded from Weather Underground for Denver, Colorado (NREL n.d., Weather Underground 2013).

\section{Building Automation System Trend Logs}

- Condenser Supply and Return - The condenser water supply and return temperature for the main condenser loop was trended via the BAS at a recording interval of 15 minutes for 2016 through 2017.

- Condenser Pump Speed - The condenser pump \#1 and \#2 speeds were trended via the BAS at a recording interval of 15 minutes for 2016 through 2017.

The condenser cooling load was calculated via the condenser pump start/stop, pump speed, and condenser supply and return temperature difference from the BAS for 2016. NREL did not install any secondary data acquisition systems and did not perform the same level of measurement and verification (M\&V) as on other GSA GPG projects because this project was financed by GSA Region 8 and not the national GSA Proving Ground. For this project, only the existing metering system data and BAS data were used to characterize the cooling tower makeup water savings (for both the baseline period and post retrofit period). A list of monitoring points, instruments, and instrument accuracy is provided in Table 4. 
Table 4: Monitoring Points and Instrumentation

\begin{tabular}{|c|c|c|c|}
\hline Monitoring Point & $\begin{array}{l}\text { Instrument } \\
\text { Description }\end{array}$ & Location & Instrument Accuracy \\
\hline $\begin{array}{l}\text { Chiller Plant } \\
\text { Energy }\end{array}$ & $\begin{array}{l}\text { Existing automated } \\
\text { electrical submeter }\end{array}$ & $\begin{array}{l}\text { Building } 95 \\
\text { chiller plant }\end{array}$ & $+/-0.5 \%$ \\
\hline $\begin{array}{l}\text { Cooling Tower } \\
\text { Makeup Water }\end{array}$ & $\begin{array}{l}\text { Existing automated } \\
\text { water submeter }\end{array}$ & $\begin{array}{l}\text { Building } 95 \\
\text { cooling tower } \\
\text { makeup }\end{array}$ & $+/-0.4 \%$ \\
\hline $\begin{array}{l}\text { Condenser Water } \\
\text { Supply and Return } \\
\text { Temperature }\end{array}$ & $\begin{array}{l}\text { BAS temperature } \\
\text { sensor }\end{array}$ & $\begin{array}{l}\text { Building } 95 \\
\text { condenser loop }\end{array}$ & $+/-10 \%$ \\
\hline $\begin{array}{l}\text { Condenser Pump } \\
\text { Speed }\end{array}$ & BAS trend point & $\begin{array}{l}\text { Building } 95 \\
\text { condenser pump } \\
\# 1 \text { and } \# 2\end{array}$ & $+/-0 \%$ \\
\hline $\begin{array}{l}\text { Outside Air } \\
\text { Temperature }\end{array}$ & Temperature sensor & $\begin{array}{l}\text { Measurement \& } \\
\text { Instrumentation } \\
\text { Data Center } \\
\text { (NREL MIDC) } \\
\text { (NREL n.d.-b); } \\
\text { Weather } \\
\text { Underground }\end{array}$ & $+/-2 \% ;+/-5 \%$ \\
\hline $\begin{array}{l}\text { Outside Air Dew } \\
\text { Point }\end{array}$ & $\begin{array}{l}\text { Combination of } \\
\text { relative humidity and } \\
\text { temperature sensor }\end{array}$ & $\begin{array}{l}\text { NREL MIDC; } \\
\text { Weather } \\
\text { Underground }\end{array}$ & $+/-2 \% ;+/-5 \%$ \\
\hline Wind Speed & Wind vane & $\begin{array}{l}\text { NREL MIDC; } \\
\text { Weather } \\
\text { Underground }\end{array}$ & $+/-2 \% ;+/-5 \%$ \\
\hline Precipitation & Rain gauge & $\begin{array}{l}\text { NREL MIDC; } \\
\text { Weather } \\
\text { Underground }\end{array}$ & $+/-2 \% ;+/-5 \%$ \\
\hline
\end{tabular}

\section{Study Design}

On-site building operators and cooling tower maintenance technicians logged water chemistry and condenser tube fouling pre and post installation. GSA has developed the water chemistry standards given in Table 5 as a guideline to determine an acceptable blowdown water quality for a given AWT, and they were adopted for this project location. Operations staff and AWT vendors performed monthly monitoring of these parameters to characterize the performance of the system. It should be noted that adherence to these ranges is not the only indicator of an AWT's success. The operation of each AWT is unique and, due to the materials used in its design, may result in water quality that falls outside the ranges defined in the project specifications. In the AWT selection process, a site should be sure to consider site-specific water quality constraints, whether due to influent potable water or discharge permit limitations. 
Table 5: Water Quality Criteria (as defined by GSA)

\begin{tabular}{|l|c|}
\hline Test & Acceptable Ranges \\
\hline T alkalinity (parts per million [ppm]) & $100-1000$ \\
\hline pH & $7.3-9.0$ \\
\hline Chloride (ppm) & $10-500$ \\
\hline Cycles & $>2$ \\
\hline Total Hardness (ppm) & $500-1500$ \\
\hline Phosphate (ppm) & 43,327 \\
\hline Conductivity (millimhos [mmHos]) & $<2400$ \\
\hline Bacteria Count (cfu) & $<80,000$ \\
\hline Water Appearance & Clear \\
\hline Iron (ppm) & $<4$ \\
\hline Calcium Hardness (ppm) & $<500$ \\
\hline Magnesium Hardness (ppm) & $<100$ \\
\hline Chlorides (ppm) & $<250$ \\
\hline Salt (ppm) & $<410$ \\
\hline Sulfates (ppm) & $<250$ \\
\hline Silica (ppm) & $<150$ \\
\hline Oxidation Reduction Potential & $<300$ \\
\hline (millivolts [mV]) & $<0.1$ \\
\hline 90-day Copper Coupon (mils per & $<4$ \\
\hline year [mpy]) & \\
\hline 90-day Mild Steel Coupon (mpy) & \\
\hline 90-day Galvanized Steel (mpy) & \\
\hline 90-day Stainless Steel (mpy) & (m) \\
\hline
\end{tabular}

\section{Data Analysis}

The chiller plant energy and cooling tower makeup water 15-minute totalizing meter readings were available for 2014 through 2017. The BAS trend logs were only available for 2016 and 2017 and there were some major data drop outs and inconsistencies in the BAS measurement points. Because the technology was installed in December 2014, the baseline year for the study was 2014. The AWT contractor analyzed the condition of the condenser tubes in early 2015, noting that the condenser tubes were significantly fouled with scale buildup from the previous cooling tower water treatment system. GSA and the cooling tower contractor undertook successful scale-reduction measures later that year, so 
the 2015 cooling season was not used in this analysis. The 2017 electrical meter data and condenser water meter data had the fewest data drop outs and were thus used as the post retrofit savings case.

The cooling tower makeup water savings was calculated using the following procedure:

- The 15-minute chiller energy usage and cooling tower makeup water was time aligned and missing data were interpolated from existing data and rolled up into daily totals for 2014 through 2017. Daily average outside air conditions were downloaded from Weather Underground for 2014 through 2017. A multivariable linear regression model was created that correlates daily cooling tower makeup water to chiller energy usage and outside air conditions for the baseline period of 2014. This multivariable linear regression model was applied to 2017 chiller energy usage and outside air conditions to estimate a baseline daily cooling tower usage and was compared to the actual 2017 daily cooling tower makeup water usage to calculate annual water savings. A 95\% confidence interval was applied to the multivariable linear regression model to characterize the range of daily calculated water savings predictions.

- BAS trend logs for 2016 were used to create a second multivariable linear regression model to determine how well the daily condenser water ton-hrs. correlated to daily chiller energy usage to support the use of daily chiller energy usage as one of the primary explanatory variables for predicting baseline daily condenser makeup water usage. 


\section{Demonstration Results}

\section{A. QUANTITATIVE RESULTS}

\section{Water Savings}

The 2014 baseline monthly cooling degree days (CDD), chiller energy usage, and cooling tower makeup water usage were calculated from 15-minute interval data and are provided in Table 6.

Table 6: 2014 Baseline Year Cooling Degree Days, Chiller Energy, Building Water, and Cooling Tower Makeup

\begin{tabular}{|c|c|c|c|c|}
\hline Month & CDD & $\begin{array}{c}\text { Chiller Energy } \\
\text { (kWh/Month) }\end{array}$ & $\begin{array}{c}\text { Building Water } \\
\text { (Gal/Month) }\end{array}$ & $\begin{array}{c}\text { Cooling Tower Makeup } \\
\text { (Gal/Month) }\end{array}$ \\
\hline Jan-14 & 0 & 1,312 & 40,865 & 1,420 \\
\hline Feb-14 & 0 & 958 & 33,363 & 647 \\
\hline Mar-14 & 0 & 1,175 & 59,050 & 240 \\
\hline Apr-14 & 0 & 3,129 & 104,810 & 29,951 \\
\hline May-14 & 18 & 16,549 & 94,085 & 151,503 \\
\hline Jun-14 & 21 & 38,777 & 172,041 & 306,721 \\
\hline Jul-14 & 22 & 65,183 & 293,218 & 469,240 \\
\hline Aug-14 & 139 & 43,167 & 200,223 & 381,024 \\
\hline Sep-14 & 68 & 29,045 & 158,000 & 293,902 \\
\hline Oct-14 & 1 & 9,435 & 122,798 & 99,273 \\
\hline Nov-14 & 0 & 1,177 & 71,413 & 2,880 \\
\hline Dec-14 & 0 & 945 & 53,671 & 1 \\
\hline Totals & $\mathbf{2 6 9}$ & $\mathbf{2 1 0 , 8 5 1}$ & $\mathbf{1 , 4 0 3 , 5 3 6}$ & $\mathbf{1 , 7 3 6 , 8 0 2}$ \\
\hline
\end{tabular}

The 2014 cooling season had much milder outside air temperatures than other representative years, with only 269 CDDs, versus over 700 CDDs in 2017 in Denver, Colorado. Consequently, the total annual cooling tower makeup water cannot be compared directly to post retrofit years as the impact of building operations and outside air conditions would not be appropriately accounted for. In order to characterize the cooling tower makeup water as a function of outside air conditions and chiller plant energy usage, a linear regression model was created based on the 2014 data set. 


\section{Linear Regression Model}

The initial multivariable linear regression model was created using the following input variables to calculate daily cooling tower makeup water usage as a function of chiller plant energy usage and outside air conditions.

- Chiller Plant Energy Usage (Energy) - daily total energy usage, calculated from 15-minute chiller plant energy usage.

- Daily Average Temperature (Avg_Temp) - daily average temperature, downloaded from weather underground.

- Daily Maximum Temperature (Max_Temp) - daily maximum temperature, downloaded from weather underground.

- Daily Minimum Temperature (Min_Temp) - daily minimum temperature, downloaded from weather underground.

- Daily Average Wind Speed (Wind) - daily average wind speed, downloaded from weather underground.

- Daily Average Dew Point Temperature (Dewpoint) - daily average dew point temperature, downloaded from weather underground.

- Daily Total Precipitation (Precip) - daily total precipitation, downloaded from Weather Underground.

- Weekday/Weekend (Wkd_Wknd) - Each weekday was given a designation of 1 and each weekend day and federal holiday was given a designation of 0 to account for days when the facility is unoccupied has different chiller energy usage and cooling tower makeup water usage patterns.

All of the variables other than the Weekday/Weekend variable were converted into coded variables that had values between -1 and 1 in order to give them all the same range of possible values and to help improve the fit of the model. A linear regression model that included all of the terms as explanatory variables, including squared and interaction terms between explanatory variables, was created to identify the variables with the highest statistical significance ( $p$-value less than 0.05 ). From this statistical significance analysis, a final linear regression model that had the highest $\mathrm{R}^{2}$ and normalized root mean square error was created and is provided in Equation 1. 


\section{Equation 1. Baseline Daily Cooling Tower Makeup Water Regression}

$$
\begin{aligned}
& \text { Cooling Tower Makeup Water } \\
& \qquad \begin{aligned}
& =c_{0}+\left(c_{1} \cdot \text { WKD_WKND }\right)+\left(c_{2} \cdot \text { CEnergy }\right)+\left(c_{3} \cdot \text { CDewpoint }\right) \\
& +\left(c_{4} \cdot \text { CEnergy }{ }^{2}\right)+\left(c_{5} \cdot \text { CEnergy } \cdot \text { CDewpoint }\right)
\end{aligned}
\end{aligned}
$$

where:

$$
\begin{aligned}
& \text { WKD_WKND }=\text { weekday or weekend } / \text { holiday }[1=\text { Weekday or } 0=\text { Weekend }] \\
& \text { CEnergy }=\text { coded daily energy usage }[-1=\min \text { to }+1=\max ] \\
& \text { CDewpoint }=\text { coded daily average dew point temperature }[-1=\text { min to }+1=\max ] \\
& \text { CEnergy }{ }^{2}=\text { coded daily energy usage squared }[-1=\min \text { to }+1=\text { max }] \\
& \text { CEnergy } \cdot \text { CDewpoint }=\text { coded daily energy usage times coded daily average dew point temperature } \\
& {[-1=\text { min to }+1=\text { max }]}
\end{aligned}
$$

The linear regression model was selected to ensure that the explanatory variables used in the model have $p$-values less than 0.05 . The explanatory variables that had the highest statistical impact were Weekday/Weekend, chiller plant energy usage, and daily average outside air dew point, which all would be expected to impact the daily cooling tower makeup water usage. The adjusted $R^{2}$ value for the model is $94.65 \%$ and the normalized root mean square error for the model is $6.89 \%$. The coefficients for each explanatory variable are provided in Table 7.

Table 7: 2014 Cooling Tower Makeup Water Linear Regression Model Coefficients

\begin{tabular}{|l|c|}
\hline \multicolumn{1}{|c|}{$\begin{array}{c}\text { Mo14 Linear Regression } \\
\text { Model Parameters }\end{array}$} & Values \\
\hline r squared & 0.9465 \\
\hline Intercept & 9456.3 coefficient \\
\hline WKD_WKND & -344.5 coefficient \\
\hline CEnergy & 444.8 coefficient \\
\hline CDewpoint & 8697.2 coefficient \\
\hline CEnergy & -8909.2 coefficient \\
\hline CEnergy x CDewpoint & 9186.9 coefficient \\
\hline
\end{tabular}

A check of model prediction was performed that compared the actual cooling tower makeup water to the modeled cooling tower makeup water. Figure 6 shows that that there is a good correlation between the two, especially given that the analysis was based on existing metering system readings and not on more accurate third-party data acquisition systems. 


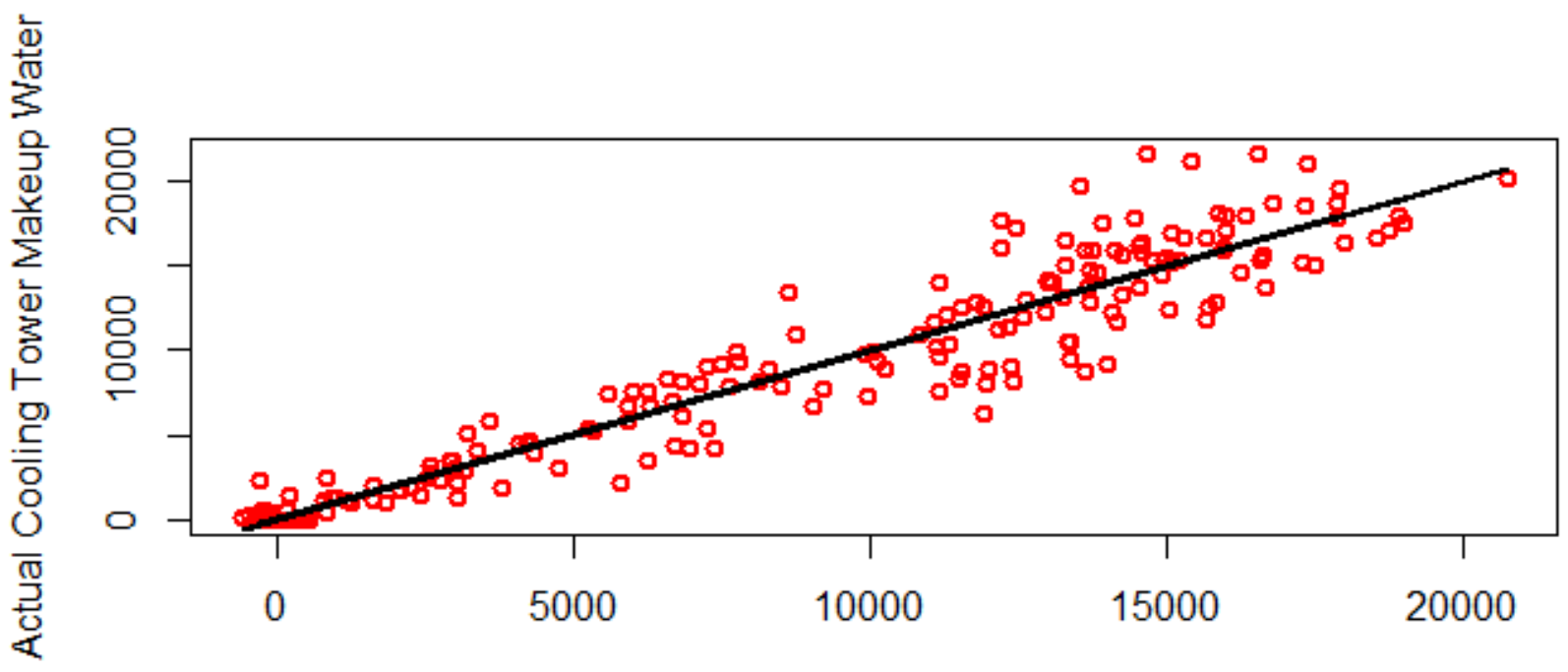

\section{Predicted Cooling Tower Makeup Water}

Figure 6: 2014 Actual Cooling Tower Makeup Water versus Predicted Cooling Tower Makeup Water Usage

As a next step, because BAS trend logs were available for 2016, the hourly condenser water load was checked against the hourly chiller plant energy usage to see if there was good agreement between the two. The chiller plant has a plate and frame heat exchanger that allows for tower free cooling, and the analysis was conducted to ensure that the chiller plant energy usage was a good predictor of chiller cooling load, as measured in condenser water ton-hrs. From this statistical significance analysis, a final linear regression model that had the highest $R^{2}$ and normalized root mean square error was created and is provided in Equation 2.

\section{Equation 2. Daily Condenser Load as a Function of Chiller Plant Energy Usage}

$$
\text { Daily Condenser Load }\left(\frac{\text { ton }}{\text { hrs }}\right)=c_{0}+\left(c_{1} \cdot \text { CEnergy }\right)+\left(c_{2} \cdot \text { CEnergy } \cdot \text { CCDD }\right)
$$

where:

$$
\begin{aligned}
& \text { CEnergy }=\text { coded daily energy usage }[-1=\min \text { to }+1=\max ] \\
& C C C D=\text { coded cooling degree days }[-1=\min \text { to }+1=\max ]
\end{aligned}
$$

The adjusted $\mathrm{R}^{2}$ for the model was $88.49 \%$ and the normalized root mean square error for the model is $7.22 \%$. Table 8 lists the coefficients for each explanatory variable. 
Table 8: 2014 Cooling Tower Makeup Water Linear Regression Model Coefficients

\begin{tabular}{|l|c|}
\hline \multicolumn{1}{|c|}{$\begin{array}{c}\text { Mo14 Linear Regression } \\
\text { Model Parameters }\end{array}$} & Values \\
\hline r squared & 0.8849 \\
\hline Intercept & $1,941.4$ coefficient \\
\hline CEnergy & $4,294.1$ coefficient \\
\hline CCDD & $-1,239.0$ coefficient \\
\hline CEnergy x CCDD & $1,181.6$ coefficient \\
\hline
\end{tabular}

A final check of model prediction was performed comparing the actual cooling tower makeup water to the modeled cooling tower makeup water. Figure 7 shows that that there is again a good correlation between the two, with the same caveat that this was based on existing metering system readings and not more accurate $3^{\text {rd }}$ party $M \& V$ equipment.

\section{Check of Model Prediction}

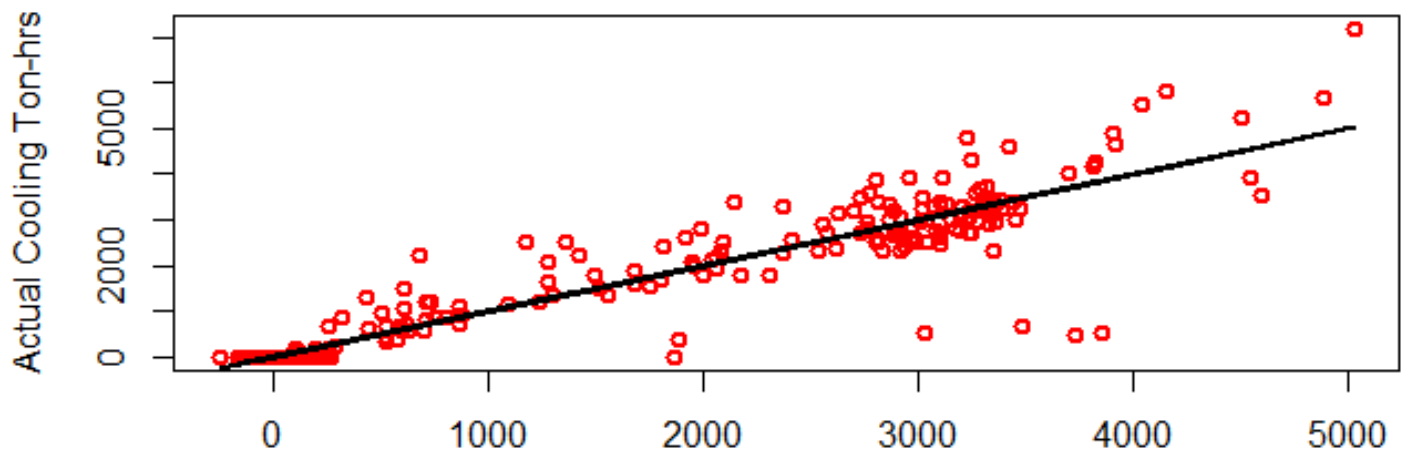

Predicted Cooling Ton-hrs

Figure 7: Actual Daily Cooling Ton-Hrs. versus Predicted Cooling Ton-Hrs.

Given that there is good agreement for both condenser ton-hrs and cooling plant energy consumption, it was determined that cooling plant energy consumption could be used in place of condenser water cooling load to model cooling tower makeup water as a function of chiller plant energy usage, as in Equation 1. The 2017 monthly CDD, chiller plant energy usage, and cooling tower makeup water usage are provided in Table 9. The 2017 cooling season was used as the savings case because, as noted above, the 2015 year was used to descale the chilled water plant's condenser coils and there were major data drop outs in the 2016 data. 
Table 9: 2017 Monthly Cooling Degree Days, Chiller Plant Energy Usage, and Cooling Tower Makeup Water

\begin{tabular}{|l|c|c|c|}
\hline Month & CDD & $\begin{array}{c}\text { Chiller Energy } \\
\text { (kWh/Month) }\end{array}$ & $\begin{array}{c}\text { Cooling Tower } \\
\text { Makeup } \\
\text { (Gal/Month) }\end{array}$ \\
\hline 1-Jan & 0 & 828 & 928 \\
\hline 1-Feb & 0 & 4,151 & 15,042 \\
\hline 1-Mar & 0 & 10,241 & 46,706 \\
\hline 1-Apr & 0 & 10,603 & 52,254 \\
\hline 1-May & 6 & 14,072 & 54,904 \\
\hline 1-Jun & 143 & 62,794 & 282,322 \\
\hline 1-Jul & 286 & 93,724 & 398,206 \\
\hline 1-Aug & 173 & 65,806 & 298,039 \\
\hline 1-Sep & 101 & 43,687 & 190,375 \\
\hline 1-Oct & 0 & 16,402 & 61,146 \\
\hline 1-Nov & 0 & 7,989 & 35,554 \\
\hline 1-Dec & 0 & 2,480 & 40,005 \\
\hline Totals & 709 & 332,776 & $1,475,482$ \\
\hline
\end{tabular}

The 2017 cooling season had 709 CDD, compared to just 269 in 2014, and the chiller plant energy usage was $332,775 \mathrm{kWh} / \mathrm{yr}$. versus $210,851 \mathrm{kWh} / \mathrm{yr}$. in 2014, indicating that the 2017 cooling season was much hotter and required significantly more chiller plant energy to meet the facility's cooling load than in 2014.

The 2017 daily chiller plant energy usage, and outside air conditions were imported into the linear regression model provided in Equation 1 to estimate baseline water consumption. A 95\% confidence interval was used to predict the lower and upper bounds of the modeled baseline cooling tower makeup water usage for the post installation measured 2017 cooling tower makeup water consumption, and the monthly results are provided in Table 10. 
Table 10: Measured versus Modeled 2017 Cooling Tower Makeup Water Consumption

\begin{tabular}{|c|c|c|c|c|}
\hline Month & $\begin{array}{l}2017 \text { Cooling } \\
\text { Tower Makeup } \\
\text { (Gal/Month) }\end{array}$ & $\begin{array}{c}\text { Modeled } \\
\text { Baseline Water } \\
\text { (Gal/Month) }\end{array}$ & $\begin{array}{l}\text { Modeled Baseline } \\
\text { Water Lower } \\
\text { Bound } \\
\text { (Gal/Month) }\end{array}$ & $\begin{array}{c}\text { Modeled Baseline } \\
\text { Water Upper } \\
\text { Bound } \\
\text { (Gal/Month) }\end{array}$ \\
\hline 1-Jan & 928 & 0 & 0 & 0 \\
\hline 1-Feb & 15,042 & 18,301 & 15,087 & 21,516 \\
\hline 1-Mar & 46,706 & 54,556 & 47,606 & 61,507 \\
\hline 1-Apr & 52,254 & 66,350 & 60,921 & 71,780 \\
\hline 1-May & 54,904 & 107,543 & 101,170 & 113,917 \\
\hline 1-Jun & 282,322 & 375,419 & 360,615 & 390,226 \\
\hline 1-Jul & 398,206 & 506,684 & 487,778 & 525,593 \\
\hline 1-Aug & 298,039 & 445,116 & 432,816 & 457,420 \\
\hline 1-Sep & 190,375 & 275,749 & 263,717 & 287,783 \\
\hline 1-Oct & 61,146 & 108,623 & 99,138 & 118,108 \\
\hline 1-Nov & 35,554 & 44,930 & 39,922 & 49,939 \\
\hline 1-Dec & 40,005 & 0 & 0 & 0 \\
\hline Totals & $1,475,482$ & $2,003,273$ & $1,908,771$ & $2,097,789$ \\
\hline
\end{tabular}

The estimated annual cooling tower makeup water savings are 527,791 gallons/ year, with a range of estimated savings from 433,288 gallons/year to 622,307 gallons/year. This corresponds to an estimated total annual cooling tower makeup water savings of $26.3 \%$, with a lower bound estimate of $22.7 \%$ and a higher bound estimate of $29.7 \%$.

\section{Water Chemistry Analysis}

During the cooling load dominated months of May through October, the average CoC increased from 7.9 CoCs during the 2014 baseline year to 11.1 CoCs in 2017, representing a $29.7 \%$ improvement in CoC. Although the $\mathrm{CoC}$ data were not used to calculate water savings, the improvements in $\mathrm{CoC}$ are directionally in line with the water savings calculated from the regression model in Table 10.

Prior to installing the AWT, the cooling towers were drained, and the contractor performed a bore-ascope of the two chiller tube condenser bundles (running a camera through the tubes to search for scaling) and found a small amount of scale buildup in both chillers. For the first few months of 2015, the existing cooling tower water treatment systems were operated in conjunction with the AWT product at much lower CoCs to descale the chillers and clean out the system. Bore-a-scope pictures from February 2017 showed significant improvement in condenser tube fouling. The operations and maintenance (O\&M) contractor servicing the facility continued its service contract and, after the initial descaling period, no additional water treatment chemicals other than bromine/chlorine biocides were used to prevent biological growth, significantly reducing the chemical usage of the tower and decreasing the 
environmental impact of the chemicals being drained via the blowdown cycle. The average annual makeup water and tower water chemistry, as well as GSA acceptable tower water chemistry ranges for calendar year 2017 is given in Table 11.

Table 11: 2017 Alternative Water Treatment Annual Average Water Chemistry

\begin{tabular}{|c|c|c|c|}
\hline \multirow[b]{2}{*}{ Test } & \multicolumn{2}{|c|}{ AWT Annual Average } & \multirow{2}{*}{$\begin{array}{c}\text { Acceptable Ranges } \\
\text { Tower }\end{array}$} \\
\hline & Makeup & Tower & \\
\hline Conductivity & 209 & 1780 & $<2400$ \\
\hline pH & 7.83 & 8.73 & $7.3-9.0$ \\
\hline P-Alk. & 0.00 & 17.25 & - \\
\hline M-Alk. & 50.92 & 287 & - \\
\hline Total -Alk & 50.92 & 304 & $100-1000$ \\
\hline Total hardness & 72 & 600 & $500-1500$ \\
\hline Calcium hardness & 55 & 452 & $<500$ \\
\hline Chlorides & 21 & 181 & $10-500$ \\
\hline Silica & 6.30 & 47.46 & $<150$ \\
\hline Conductivity Cycles & - & 9.54 & $>2$ \\
\hline Total Hardness Cycles & - & 9.94 & - \\
\hline Calcium Hardness Cycles & - & 9.88 & - \\
\hline Chloride Cycles & - & 9.74 & - \\
\hline Silica Cycles & - & 7.84 & - \\
\hline $\begin{array}{c}\text { Oxidation Reduction } \\
\text { Potential }\end{array}$ & 295 & 194 & $>300$ \\
\hline Bacteria & - & 960 & $<80,000$ \\
\hline Iron & 0.13 & 0.27 & $<4$ \\
\hline Copper & 0.11 & 0.13 & - \\
\hline Hydrogen Peroxide & - & 1.24 & - \\
\hline
\end{tabular}

For 2017, the annual average conductivity-based CoC was 9.54, and all of the tower water chemistry values were within the GSA designated ranges except for oxidation reduction potential, which was lower than the required 300 minimum.

\section{B. COST-EFFECTIVENESS}

The AWT company gifted the GSA Denver Federal Center one processing cabinet and an additional cabinet was installed during the pilot test. The equipment costs for the two AWT processing units was $\$ 29,780$ and the installation cost was $\$ 2,970$, for a total cost of $\$ 32,750$ (\$65.5/ton). The 12 -month 
service agreement was $\$ 3,300$ (\$275 per month). Table 12 shows the water rates for 2011 through 2014. Over this period, water rates rose an average of $6.7 \%$ per year.

Table 12: Denver Water Rates 2011 to 2014

\begin{tabular}{|c|c|c|}
\hline Year & Water Cost & $\begin{array}{c}\text { Increase Over } \\
\text { Previous Year }\end{array}$ \\
\hline & (\$/1,000 gallons) & $(\%)$ \\
\hline 2011 & 3.5 & - \\
\hline 2012 & 3.6 & $6.0 \%$ \\
\hline 2013 & 3.8 & $5.0 \%$ \\
\hline 2014 & 4.0 & $9.0 \%$ \\
\hline
\end{tabular}

Based on the annual water cost inflation rate assumption of 6.7\% per year (Based on 2011 to 2014 increases in water rates, the 2017 water cost estimate was $\$ 4.80 / \mathrm{kgal}$. The actual rate was $\$ 4.82 / \mathrm{kgal}$, so the estimated annual inflation rate has been consistent over the last 6 years.

Each gallon of water saved reduced the amount discharged to the sewer and subsequent costs incurred by the site. This is because the water saved with improved water treatment technologies was associated with the blowdown component of cooling tower water use. The blowdown therefore would not be discharged to the sewer system, saving that portion of the water costs. The 2017 water rate was $\$ 4.82 / \mathrm{kgal}$ and the 2017 sewer rate was $\$ 2.33 / \mathrm{kgal}$, for a total cost of $\$ 7.14 / \mathrm{kgal}$. The annual water savings, cost savings, and economics for the system are provided in Table 13. 
Table 13: Annual Cost Savings and Economics

\begin{tabular}{|c|c|c|c|c|}
\hline & $\begin{array}{l}\text { Baseline } \\
\text { (Before) }\end{array}$ & $\begin{array}{r}\text { Tested } \\
\text { Technology } \\
\left(\text { After) }{ }^{1}\right.\end{array}$ & $\begin{array}{r}\text { Difference w/ } \\
\text { Local Sewer + } \\
\text { Water Rate } \\
\text { (\$7.14/kGal.) }\end{array}$ & $\begin{array}{r}\text { Difference } \\
\text { w/ GSA Avg. } \\
\text { Water Rate } \\
\$ 16.76 / \mathrm{kGal} .\end{array}$ \\
\hline Installation (\$) & $\mathrm{N} / \mathrm{A}$ & $\$ 32,750$ & $\$ 32,750$ & $\$ 22,487$ \\
\hline Installation Cost (\$/ton) & & $\$ 65.50$ & $\$ 65.50$ & $\$ 44.97$ \\
\hline Annual Maintenance & $\$ 5,855 / y r$ & $\$ 3,333 / y r$. & $\$ 2,522 / y r$ & $\$ 2,522 / y r$. \\
\hline $\begin{array}{r}\text { Annual Water Consumption } \\
\text { (Gallons/yr.) }\end{array}$ & $2,003,273$ & $1,475,482$ & 527,791 & 527,791 \\
\hline Annual Water Costs(\$/yr.) & $\$ 14,303$ & $\$ 10,535$ & $\$ 3,768$ & $\$ 8,846$ \\
\hline Annual Energy Costs (\$/yr.) & $\$ 0$ & $\$ 1,041$ & $\$ 1,041$ & $\$ 578$ \\
\hline Simple Payback & & Yrs. & 6.2 & 2.1 \\
\hline Savings-to-Investment Ratio & \multicolumn{2}{|c|}{ Integer value between 0 and 100} & 2.4 & 7.2 \\
\hline
\end{tabular}

The new cooling tower operations and maintenance contract for the AWT saved the site $\$ 2,522$ per year, with a $50 \%$ reduction in man hours. The two AWT units had a combined power draw of $1.2 \mathrm{~kW}$ and operated for $8,760 \mathrm{hrs} . / \mathrm{yr}$., for a total power consumption of 10,512 kWh/yr. and an estimated energy cost of $\$ 1,137 / \mathrm{yr}$. The annual water cost savings was $\$ 3,768$ per year (using a combined water sewer rate of $\$ 7.14 / \mathrm{kgal}$.) and the simple payback period is 6.2 years, with a savings-to-investment ratio of 2.4 , using a 15 year project lifetime. Given that for future installations of this size, both GSA and the vendor have confirmed that just one AWT processing unit would be needed, the installed cost for that case was estimated to be $\$ 22,487$, with an energy usage of $5,250 \mathrm{kWh} / \mathrm{yr}$., at a cost of $\$ 578 / \mathrm{yr}$. Using GSA's national average combined water and sewer rate of $\$ 16.76 / \mathrm{kgal}$., the annual water savings would have been $\$ 8,846 / \mathrm{yr}$, with a simple payback of 2.1 years and a savings-to-investment ratio of 7.2.

\section{QUALITATIVE RESULTS}

The installation time for the product was only a few hours as the unit only requires a simple wall mounting and connection of the injector hose to the cooling tower. This few hours to install the unit was less than the performance metric requirement of 2 days or less. 


\section{Summary Findings and Conclusions}

\section{A. OVERALL TECHNOLOGY ASSESSMENT AT DEMONSTRATION FACILITY}

GSA installed the AWT at Building 95 at the Denver Federal Center in an effort to see whether the technology could maintain adequate water quality while conserving water and reducing operating costs. The determination of adequate water quality was made based on a previously-developed set of cooling tower water chemistry requirements from GSA. The calculated annual makeup water savings is provided in Table 10 and estimated to range from $22.7 \%$ to $29.7 \%$. The calculated simple payback period for this demonstration was 6.2 years and the AWT showed favorable economics at the demonstration facility.

Given that the bore-a-scope of the two chiller tube condenser bundles found scaling prior to installing the AWT and a reduction in scaling after implementation in February of 2017, the system also has the potential to reduce energy usage from diminished condenser tube scaling and reduce the number of tube cleanings. Although the chiller plant had 15-minute interval electrical meters, the energy savings could not be quantified due to the lack of BAS trend logs for the chiller plant for the baseline year of 2014.

The simplicity of this product, ease of installation, and reduction in on-site chemical usage all make this technology a good candidate for future AWT deployments.

\section{B. LESSONS LEARNED AND BEST PRACTICES}

The installation of the AWT system only required a small footprint and a simple tie-in process. Since the installation and the removal of the technology are not invasive to the balance of the system, the risk of adopting this technology is reduced. For this installation, it only took a few hours to install the product and connect it to the existing cooling tower.

One of the primary drivers from the Denver Federal Center staff for wanting to test this AWT product was that they were searching for a system that would work in smaller building applications, where there may not be a full-time mechanic or on-site cooling tower O\&M contractor. This product is unique in that it can be used without additional monitoring other than a low-cost service agreement.

For future installations, Denver Federal Center staff have indicated that they would suggest leasing the technology as part of the service contract with the vendor instead of purchasing it, given that the installation is very quick and potential removal of the technology would not be invasive to the balance of system.

\section{DEPLOYMENT RECOMMENDATIONS}

This AWT technology met all the predetermined success criteria for water savings, reduction in chemical costs, water chemistry, cost-effectiveness, and ease of installation at the test location. For similar buildings in climates with cooling seasons of at least as long as that of the test location (climate zone $5 B)$, this technology could offer cost and water savings, as well as environmental benefits and reduced 
system O\&M. Due to these factors, and the system's ease of installation, this AWT should be considered for further deployment.

Cooling tower performance depends on a variety of factors, however, many of which are locationspecific. Variables such as seasonal changes and ambient air quality are specific to the site location and tower location on the site (e.g., airborne particulate matter) and have the potential to affect the observed performance of the evaluated technology. These factors can also contribute to biological growth or mineral deposits that would require chemical treatments and additional maintenance. If the site has higher total dissolved solids or particulate matter, this technology should be used in conjunction with a side stream filtration system.

Given that cooling tower performance is a function of wet bulb temperature, the amount of cooling delivered for each technology and the water savings will also vary by site. Sites in hot/dry climates with low wet bulb design temperatures will typically have the largest savings.

Potable water quality is highly variable across the United States. The performance of AWT technologies is a function of the quality of influent water that is treated. Locations with high hardness, $\mathrm{pH}$, etc., typically require higher water and chemical usages. These sites will have the greatest opportunity for savings.

Rebate opportunities may also be available through local water utilities to implement water conserving technologies. The availability of these financial incentives can make the technology's implementation even more cost-effective.

\section{Market Potential within the GSA Portfolio}

The first step in evaluation of further deployment of an AWT technology is the identification of buildings in the GSA portfolio that have water-cooled chillers. These are typically larger buildings with high cooling loads that benefit from the improved efficiency of water-cooled chiller plants (and where the higher initial cost of a chiller plant is warranted due to higher loads).

The next step in site selection is identifying sites where the AWT technology will perform well economically. To assist GSA in identifying sites that have high potential water and/or cost savings, NREL previously used the whole-building modeling software EnergyPlus ${ }^{\mathrm{TM}}$ to model water savings potential in an NREL/GSA GPG report entitled Alternative Water Treatment Technologies for Cooling Tower Applications. The "Large Office" building model was selected from the Commercial Reference Buildings that are developed and maintained by the U.S. Department of Energy and NREL (DOE n.d.). The Commercial Reference Buildings are a set of EnergyPlus building models that represent typical building types and constructions and include climate-specific models (per building type) for each of the sixteen different ASHRAE climate zones. For the modeling analysis included in this report, the "post-1980" construction model was used.

The large office building model is a $498,588 \mathrm{ft}^{2}$ office building that is cooled via a water-cooled chiller. The standard cooling tower model in EnergyPlus defaults to blowdown operation that maintains a CoC of 3.0. In order to evaluate the potential impact of AWT in the national GSA building portfolio, the large office building model was simulated in 16 different U.S. cities, one representative city for each of the 16 ASHRAE climate zones. For each climate zone, the model was run three times: (1) with the cooling tower 
set to maintain a $3.0 \mathrm{CoC},(2)$ with the cooling tower set to maintain a $10.0 \mathrm{CoC}$, and (3) with the cooling tower set to maintain a $15.0 \mathrm{CoC}$. The EnergyPlus default of $3 \mathrm{CoC}$ was established as the baseline, representative of a standard water treatment approach for water-cooled chillers. The 10.0 and $15.0 \mathrm{CoC}$ simulations represent a range of concentrations that have been shown to be achievable by AWT technologies in this report. Figure 8 shows the annual evaporation (in thousands of gallons water) and the annual water savings (over the baseline blowdown at $3.0 \mathrm{CoC}$ ) for 10.0 and $15.0 \mathrm{CoC}$. The cities with larger numbers of cooling degree days and more arid climates show the greatest water savings.

Additionally, as shown in Figure 8, when the CoC is above 10 CoCs, the blowdown water usage is reduced dramatically, and the evaporative portion of the cooling tower water makeup usage makes up the majority of the water usage. Note also that the vast majority of the water savings are achieved by 10 CoCs.

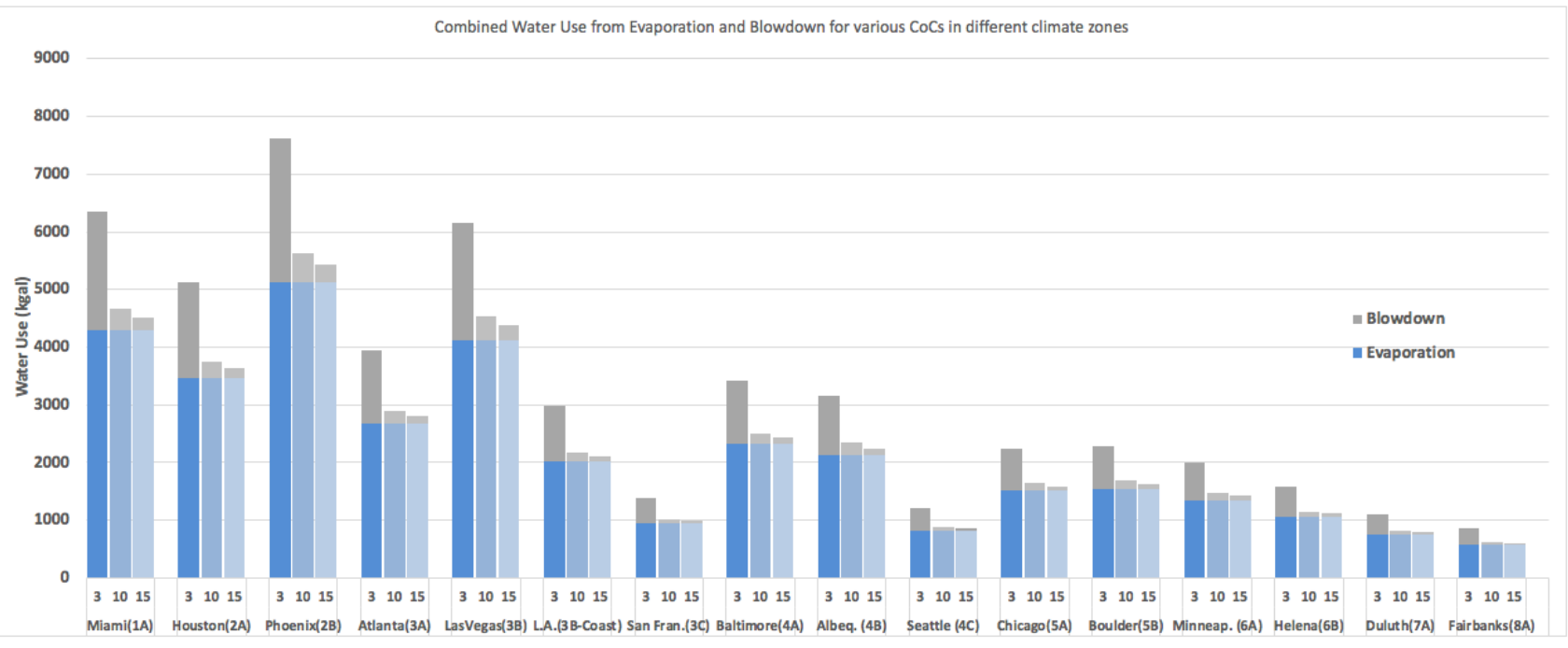

Figure 8: Modeled Water Evaporation and Blowdown Savings across ASHRAE Climate Zones

The water savings numbers were then translated into annual cost savings using site specific water rates. Combined water and sewer rates were obtained from local water utilities for each city, assuming each site is on a 6-in. water line and uses more than 200,000 gallons per month. The annual water savings for each location were multiplied by the combined water rate for each city. The results from this analysis are presented in Figure 9. 


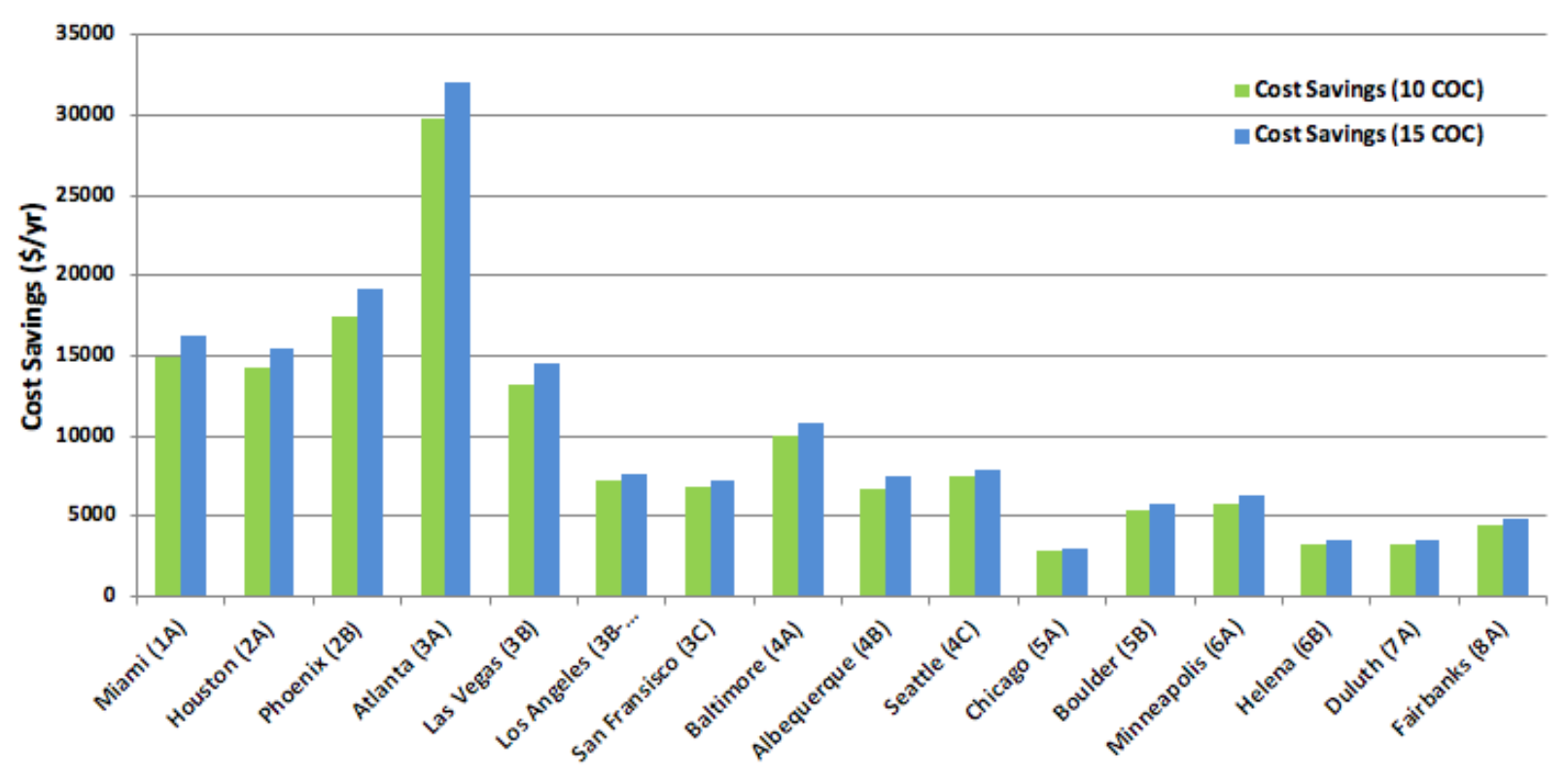

Figure 9: Estimated Yearly Cost Savings by Climate Zone

The wide variation in water costs between the different cities results in a significantly different picture in cost savings than is seen in water savings. Cities with high water rates (such as Atlanta, Georgia) generate the largest annual cost savings despite not having the largest total water savings. Table 14 gives the water rates used in this evaluation (current as of May 2018).

Table 14: Combined Water and Sewer Rates for Sample Cities across Each of the 16 ASHRAE Climate Zones

\begin{tabular}{|c|c|c|c|}
\hline $\begin{array}{c}\text { Location } \\
\text { (Climate Zone) }\end{array}$ & $\begin{array}{c}\text { Combined Water and } \\
\text { Sewer Rate } \mathbf{( \$ / k g a l )}\end{array}$ & $\begin{array}{c}\text { Location } \\
\text { (Climate Zone) }\end{array}$ & $\begin{array}{c}\text { Combined Water and } \\
\text { Sewer Rate (\$/kgal) }\end{array}$ \\
\hline Miami (1A) & 13.62 & Albuquerque (4B) & 4.98 \\
\hline Houston (2A) & 10.38 & Seattle (4C) & 25.18 \\
\hline Phoenix (2B) & 7.76 & Chicago (5A) & 7.76 \\
\hline Atlanta (3A) & 29.12 & Boulder (5B) & 9.32 \\
\hline Las Vegas (3B) & 8.25 & Minneapolis (6A) & 9.98 \\
\hline LA (3B-Coast) & 8.88 & Helena (6B) & 8.30 \\
\hline San Francisco (3C) & 24.01 & Duluth (7A) & 13.51 \\
\hline Baltimore (4A) & 12.30 & Fairbanks (8A) & 22.07 \\
\hline
\end{tabular}

To gain an appreciation of the market potential for GSA, approximate system costs were used to calculate a savings-to-investment ratio (SIR) for each city. Note that this calculation assumes that the annual operating costs associated with these systems are the same after the install as they were with the original system. The ratios denoted here are rough estimates, considering the assumptions that the 
original system was operating at $3 \mathrm{CoC}$, the new system would achieve $10 \mathrm{CoC}$, and that the annual operating costs remain the same pre- to postinstallation, yet they give a feeling for the critical variables driving economic viability of the system in various U.S. locations. The SIRs for a high installed cost assumption $(\$ 35,000)$ and a low-cost assumption $(\$ 20,000)$ are shown in Figure 10 and Figure 11, respectively. The figures show the modeled SIRs for a given water and wastewater combined rate across various climate zones. The SIR calculation assumes a 15-year project life, $10 \mathrm{CoC}, \$ 2,522 / \mathrm{yr}$ in O\&M savings and onsite electrical costs that are based on the local electric rates.

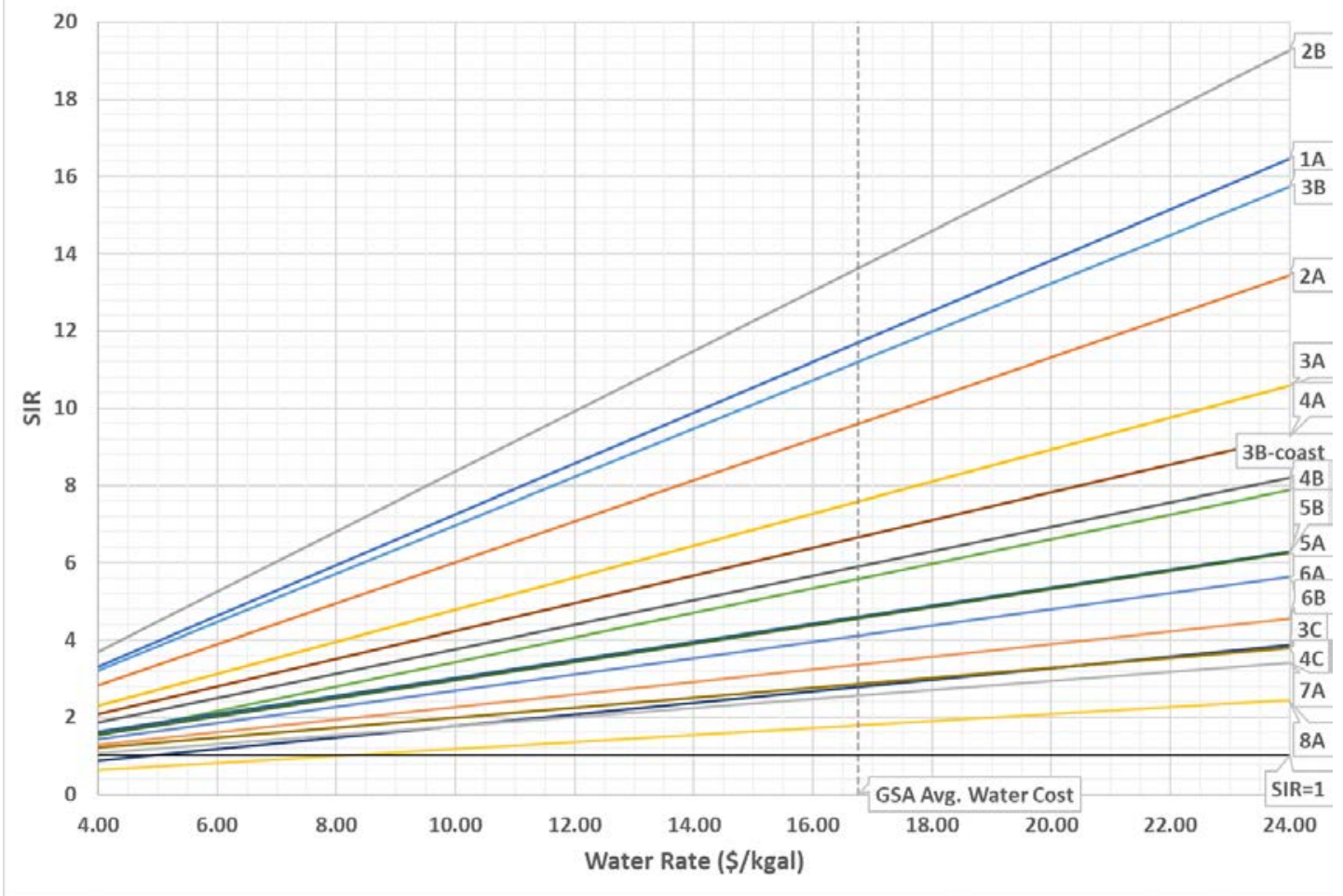

Figure 10. Savings-to-Investment Ratio for Same System in Evaluated Climate Zones for Various Water Rates: High-Cost Scenario

For the high-cost scenario, the AWT is life cycle cost-effective $(S I R>1)$ across all 16 climate zones when the combined water and sewer rate is more than $\$ 8 / \mathrm{kgal}$. 


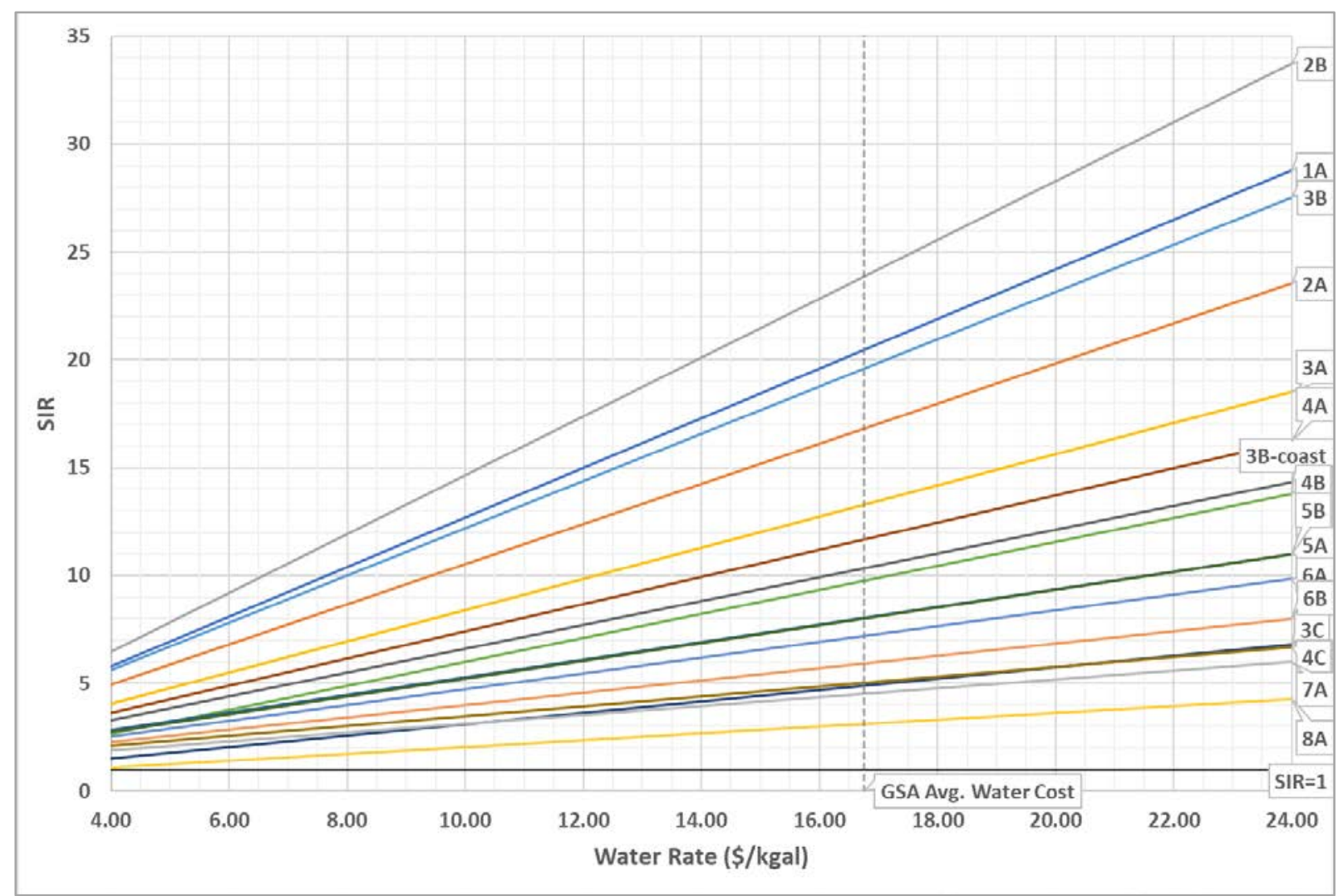

Figure 11: Savings-to-Investment Ratio for Same System in Evaluated Climate Zones for Various Water Rates: Low-Cost Scenario

For the low-cost scenario, the AWT is life cycle cost-effective ( $S I R>1)$ across all 16 climate zones when the combined water and sewer rate is more than $\$ 4 / \mathrm{kgal}$. For this particular AWT, the technology has the potential to be cost-effective in every GSA region throughout the United States, given that all of them have combined water and sewer rates of more than $\$ 4 / \mathrm{kgal}$. 


\section{Deployment Guidance (GSA Only)}

\section{A. INSTALLATION AND COMMISSIONING}

The technology was easy to install as the unit can be mounted on a wall and air tubing is run from the location of the AWT system to the cooling tower basin and an air diffuser is installed to diffuse the air in the cooling tower water. The system does not require decommissioning of the existing cooling tower treatment system or any other mechanical system within the building and takes less than 1 day to install.

\section{B. IMPACT ON FACILITY OPERATIONS}

This product can work well in smaller building applications, where there may not be a full-time mechanic or on-site cooling tower O\&M contract. This product is unique in that is has the ability to be used without additional monitoring aside from a low-cost service agreement and can also be used in larger buildings to reduce the annual chemical costs and O\&M contract costs. For any water treatment system, care should be taken in negotiating an O\&M agreement with the original equipment manufacturer or its partner. Providing good cleaning and servicing of the systems, as well as good customer service are key to the acceptance of the systems by the site staff. The agreements should not require that site personnel take on additional duties like water sampling or cleaning.

\section{IT SECURITY AND CONTINUITY OF CONNECTIVITY}

The controls for the AWT system are self-contained within the unit and there is no connection to the BAS or other IT security related issues.

\section{TECHNOLOGY MARKET READINESS}

The AWT technology is commercially available and distribution and installation channels are in place. There are numerous installations of the AWT technology in the United States, varying in size and application. Fabrication of these systems is relatively simple and the lead times for new installations are not expected to be lengthy.

\section{E. TECHNOLOGY SPECIFICATIONS}

If the technology evaluation has been successful and the technology has potential for deployment within GSA, support development of a technical specification that GSA can use for procurement. 


\section{Appendices}

\section{A. REFERENCES}

DOE (U.S. Department of Energy). n.d. Office of Energy Efficiency and Renewable Energy. Accessed April 14, 2014. http://energy.gov/eere/buildings/commercial-reference-buildings.

EPA (Environmental Protection Agency). N.d. Saving Water In Office Buildings, Accessed December 10, 2018

https://www.epa.gov/sites/production/files/2017-01/documents/ws-commercial-factsheet-offices.pdf

NREL (National Renewable Energy Laboratory). n.d.-a. Solar Radiation Research Laboratory, Accessed January 2018. https://midcdmz.nrel.gov/srrl bms/.

NREL. n.d.-b. Measurement and Instrumentation Data Center. Accessed November 25, 2018.

https://midcdmz.nrel.gov.

Silver Bullet. n.d.-a. Advanced Oxidation Process. Accessed November 24, 2018.

https://www.silverbulletcorp.com/silver-bullet-advanced-oxidation-process/

Silver Bullet. n.d.-b. Product Specifications. Accessed November 25, 2018.

https://www.silverbulletcorp.com/wp-content/uploads/Data-Center-AOP-Tech.pdf.

Weather Underground. 2013. Denver, Colorado. Accessed June 18, 2013.

https://www.wunderground.com/history/airport/KDEN/2013/06/18/DailyHistory.html. 


\title{
B. GLOSSARY
}

\begin{abstract}
Advanced Oxidation
Process (AOP)

A process by which ultraviolet light and other procedures modify an airstream to produce negatively charged hydroxyl groups $(\mathrm{OH}-)$. These can then bind to contaminants in water and remove them.
\end{abstract}

\section{Building \\ Automation System \\ (BAS)}

Biocides \& Algicides

Blowdown

Bore-a-Scope

Chiller

Cooling Tower

Corrosion Inhibitors

Cycles of

Concentration

(CoCs)

Induced Draft

Cooling Tower

Makeup Water
Provides automated centralized control of the facilities heating, ventilating, and airconditioning (HVAC) system.

Added substances or chemicals that prevent biological and algal growth in water.

The higher mineral content water that is periodically drained from a cooling tower and replaced with makeup water to prevent the solid concentration in the tower water from rising to a level that would lead to precipitation.

A device with an eyepiece on one end and a camera or lens on the other, connected by a tube. It facilitates visual inspection of a pipe or other hard-to-see area.

A device that cools by removing heat from a working fluid as it undergoes compression and expansion in a closed-loop system, with a means of ejecting heat. The cooled working fluid can then be used to cool a building space (usually after passing through a heat exchanger).

A heat rejection device that uses an evaporative cooling process to reject heat to the atmosphere from a water-cooled chilled water plant.

Additives that prevent corrosion in water-carrying pipes.

How many times greater the concentration of solids in cooling tower water is than the fresh makeup water. GSA requires cooling towers to have a CoC of at least 2.

A cooling tower with a fan at the outlet that aids in pulling moisture-filled air out of the tower and away from the air inlet.

Fresh water that is added to a cooling tower to dilute mineral impurities and maintain water volume.

Scale calcium, silica, magnesium, or chlorides. It can build up inside pipes, impeding flow. 


\section{MANUFACTURER CUT SHEET}

The product specifications sheet is provided in Figure 12 (Silver Bullet n.d.-b).

\section{Product Specifications}

\begin{tabular}{|c|c|c|}
\hline & \multicolumn{2}{|c|}{ Model Number } \\
\hline & CT140 & СТ230 \\
\hline Sleeve Power Treatment Capacity & Power 4.0 allows $0-400$ tons & $\begin{array}{l}\text { Power } 13.0 \text { allows } 401-1,200 \text { tons } \\
\text { Power } 16.0 \text { allows } 1,201-1,600 \text { tons } \\
\text { Power } 20.0 \text { allows } 1,601-2,000 \text { tons }\end{array}$ \\
\hline Processor Sleeve(s) & $\begin{array}{l}1 \text { sleeve, } 161 / 2 \text { in long, } \\
11 / 2 \text { in diameter }\end{array}$ & $\begin{array}{l}2 \text { sleeves, } 351 / 2 \text { in long, } \\
11 / 2 \text { in diameter }\end{array}$ \\
\hline Power Specifications & 3.3 amps @ 120V & 6.6 amps (1) $120 \mathrm{~V}$ \\
\hline Weight & 43 pounds & 101 pounds \\
\hline Dimensions of Enclosure & 20 in $\mathrm{H} \times 15$ in $W \times 6$ in D & 45 in $\mathrm{H} \times 24$ in W $\times 10$ in D \\
\hline $\begin{array}{l}\text { Dimensions and Weight of } \\
\text { Shipment Box }\end{array}$ & $\begin{array}{l}13 \text { in } \times 26 \text { in } \times 26 \text { in } \\
8 \text { lbs. }\end{array}$ & $\begin{array}{l}17 \text { in } \times 60 \text { in } \times 32 \\
20 \text { lbs. }\end{array}$ \\
\hline Enclosure Type & \multicolumn{2}{|c|}{ NEMA 3R } \\
\hline Digital Touch Screen & Not Included & Remote HMI Included \\
\hline Compressor & 1, GAST-MOA-P101-AA & 2, GAST-MOA-P101-AA \\
\hline System Flow & \multicolumn{2}{|c|}{$\begin{array}{c}14 \mathrm{~L} / \mathrm{min} \text { @ free flow } \\
8.5 \mathrm{~L} / \mathrm{min} \text { @ } 1 \mathrm{bar} \\
4.2 \mathrm{~L} / \mathrm{min} \text { @ } 2 \mathrm{bar} \\
4.7 \mathrm{~L} / \mathrm{min} @ 30 \mathrm{PSI} \text { though Processor Sleeves }\end{array}$} \\
\hline Depth of Basin or Sump Allowed & $1.5^{\prime}-20^{\prime}$ & $1.5^{\prime}-20^{\prime}$ \\
\hline Pressure Sensor Range & \multicolumn{2}{|c|}{$-10.0 \mathrm{PSI}$ to $30.0 \mathrm{PSI}$} \\
\hline Current Sensor Range & \multicolumn{2}{|c|}{0.25 amps to 15 amps } \\
\hline Certifications & \multicolumn{2}{|c|}{$\begin{array}{l}\text { - Registered with UL International - verified for safe } \\
\text { electrical operation } \\
\text { - Certified by NSF International - certified NSF/ANSI Standard 61: } \\
\text { Drinking Water Systems Components - Health Effects }\end{array}$} \\
\hline
\end{tabular}

Figure 12. Alternative Water Treatment Product Specifications 